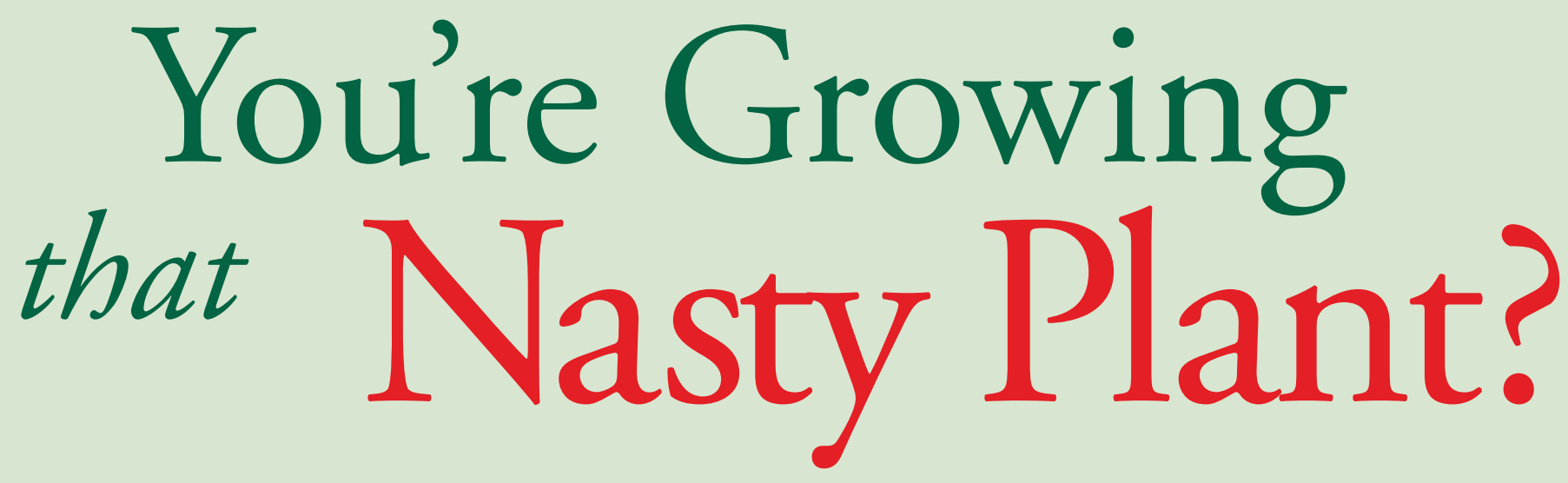

Native plant propagators are often called upon to grow some unusual plants for unusual projects. This collection of 4 propagation protocols highlights irritating plants-irritating in what they can do to our skin and sometimes irritating in their difficulty to be propagated. However, these plants have important ecological niches and a couple of them have importance to the herbal market. Read on. . you may find some aspect of these nasty plants that really intrigues you. I for one am interested in the purported hair-raising abilities of stinging nettle!

—The (balding) Editor

\title{
Propagation Protocol for Devil's Club (Oplopanax horridus)
}

KEY WORDS: seed propagation, stem cuttings, divisions

NOMENCLATURE: ITIS (2000)
Devil's club (Oplopanax horridus) seedlings at Glacier National Park Native Plant Nursery.

\section{TARA LUNA}

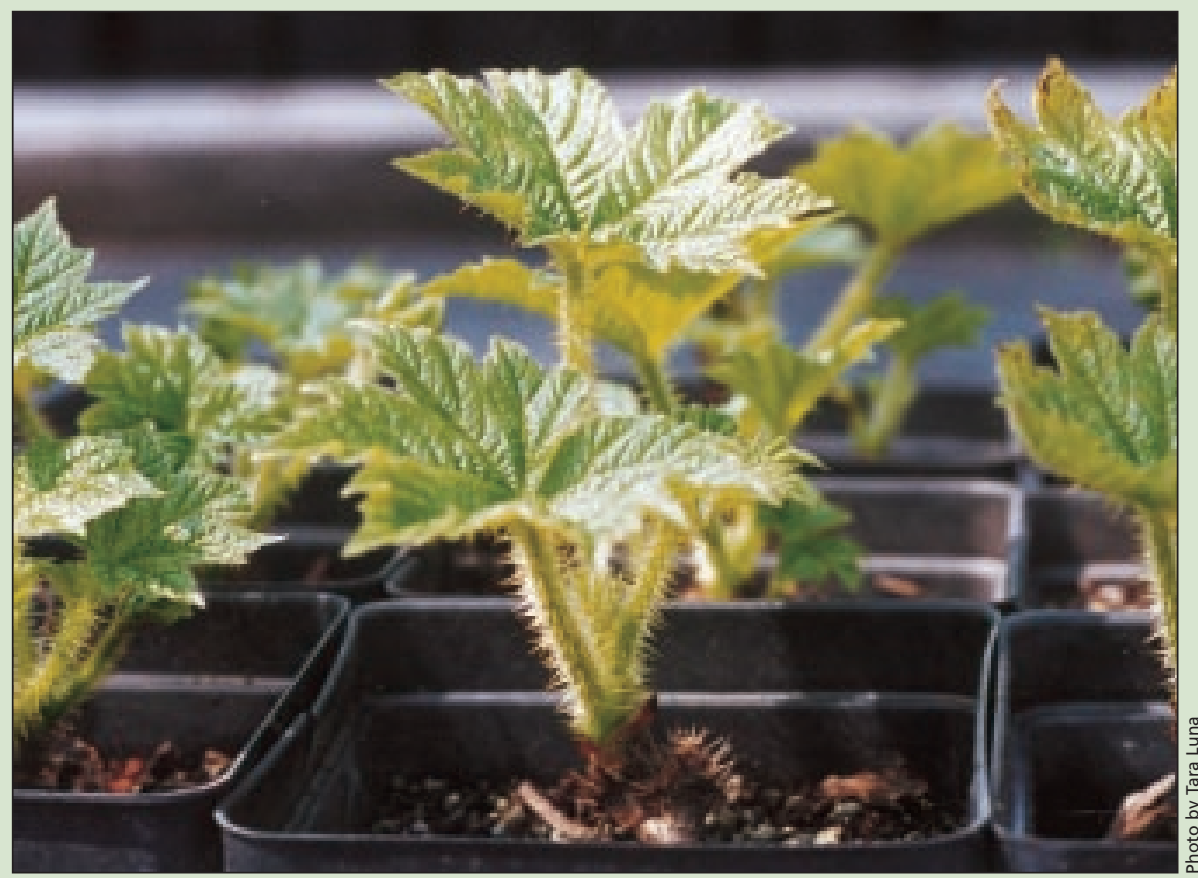


For anyone hiking through devil's club (Oplopanx horridus Miq. [Araliaceae]) habitat, they have probably regretted not bringing a pair of tweezers in their backpack. Brushing against this spiny shrub results in festering splinters and unpleasant words. The Latin name descriptively translates as "a prickly porcupine ginseng." It is an easy plant to identify and a difficult one to forget!

The very spiny shrub grows up to 3 m (9 ft) tall, with large palmately lobed leaves. Veins of the leaves and the stems are covered with sharp prickles. Flowers are greenish white and are borne in a terminal cluster during spring. The bright red fruits mature in July and August, each bearing 1 to 3 tan-colored seeds.

Devil's club is found in moist woods and thickets and along streams and seepages from sea level to the subalpine zone (0 to $1524 \mathrm{~m}$ [0 to $5000 \mathrm{ft}$ ) $)$. It is found from Alaska south along the Pacific coast to southern Oregon, extending east to southwestern Yukon Territory, central Alberta and the Rocky Mountains of Idaho and Montana, with disjunct populations around Lake Superior and Lake Michigan (Hitchcock and Cronquist 1996).

For all its ferociousness, devil's club has many redeeming properties and uses. It belongs to the same family as American, Asian, and Siberian ginseng, and like ginseng, it is used as a general tonic and system-strengthening herb. Many Pacific Northwest and Alaskan native groups use devil's club root tea for colds, arthritis, toothaches, stomach problems, gallstones, and as a blood medicine. It is also used as an external wash for boils and festering skin irritations and insect bites (Moerman 1998). An extract of the inner bark has been shown to have anti-bacterial and antifungal properties (Marles and others 1999). Indigenous people have used it to treat tuberculosis and cancer. The traditional uses of devil's club as an anti-diabetic and studies regarding its blood-sugar-lowering activity have been reviewed (Marles and Farnsworth 1995).

Some coastal groups used stem sections of devil's club as fish lures. Other groups used the charcoal of devil's club mixed with grease as a black face paint or as a tattoo dye inserted under the skin. Devil's club is still regarded as a protective force in some localities. It is placed above doorways, on fishing boats or worn as an amulet to ward of evil. Traditionally, the smoke from burning plants was used to scare off disease causing spirits (Turner 1998).

\section{RATIONALE FOR PROPAGATION}

Devil's club is propagated at the Glacier National Park Native Plant Nursery for restoration projects in the Avalanche Creek drainage. It is a component of the mature western redcedar (Thuja plicata Donn. [Cupressaceae]) habitat and can form dense patches in moist seepage areas and swales in the under story of the forest. It is an effective species for blocking undesired off-trail use in suitably moist to wet sites that are sensitive to trampling. The development of propagation techniques is also desirable to restore the species to areas that have been over harvested in other portions of its range. Perhaps devil's club can be effectively propagated on small farms or nurseries in the near future to relieve collecting pressure from natural stands.

Devil's club is also utilized as an ornamental landscape shrub. The large leaves and course texture is desired by some as a specimen plant or as an effective barrier on the edge of the garden (Kruckeberg 1989). Wildlife uses devil's club as a food source; birds eat the red berries and grizzly and black bears eat leaves and young shoots in spring and ripe berries in fall (USDA 2001).

\section{PROPAGATION}

Devil's club can be propagated by seeds or vegetatively from stem tip cuttings. In Glacier National Park, Montana, seeds are collected in July and August when fruits have fully matured. Seeds most likely exhibit a combination of morphological and physiological dormancy. Morphological and physiological dormancy is exhibited by the related genus Panax, and requires prolonged periods of warm and cold stratification for after ripening of the embryo and to break the physiological dormancy (Baskin and Baskin 1998).

At Glacier National Park Native Plant Nursery, seeds are placed in a 72-h running water soak to remove any inhibitors and fully imbibe seeds before stratification. We treat freshly harvested seeds with a $400 \mathrm{~d}$ stratification-four 100 -d-long periods of alternating warmmoist $\left(20^{\circ} \mathrm{C}\left[68^{\circ} \mathrm{F}\right]\right)$ and cold-moist (1 $\left.{ }^{\circ} \mathrm{C}\left[34^{\circ} \mathrm{F}\right]\right)$ stratification beginning with the warm-moist treatment. Seeds germinate after the second cold-moist stratification and initial establishment and growth of seedlings is slow.

Seedlings form firm root plugs in 2 to 3 $y$, depending on container size (Wick and others 2001).

Growing medium is a 2:1:1 (v:v:v) milled spaghnum peat moss:perlite:vermiculite with Osmocote controlled release fertilizer $\left(13 \mathrm{~N}: 13 \mathrm{P}_{2} \mathrm{O}_{5}: 13 \mathrm{~K}_{2} \mathrm{O} ; 8\right.$ to 9 month release rate at $\left.21{ }^{\circ} \mathrm{C}\left[70{ }^{\circ} \mathrm{F}\right]\right)$ and Micromax fertilizer (12\% S, $0.1 \%$ B, $0.5 \% \mathrm{Cu}, 12 \% \mathrm{Fe}, 2.5 \% \mathrm{Mn}, 0.05 \%$ $\mathrm{Mo}, 1 \% \mathrm{Zn})$ at the rate of $2 \mathrm{~g}(0.07 \mathrm{oz})$ of Osmocote and $1 \mathrm{~g}$ of Micromax per $800-\mathrm{ml}$ container. Plants have a shallowly rhizomatous root system and will require shallow square containers in order to obtain firm root plugs.

Seedlings require shade throughout nursery production and for establishment on the outplanting site. Other effective seed propagation techniques are currently being investigated in Alaska. Devil's club readily germinates in the wild after passing through the digestive system of brown bears and a mild but rapid scarification simulating the action of stomach acid on seeds may prove to be an effective treatment for breaking seed dormancy (Ianson 2000). The Alaska Plant Materials Center in Palmer, Alaska, is the priority site for devil's club in the National Germplasm System. Mycorrhizal relationships have been found and are currently being investigated.

Because of the delayed germination observed on seed propagated plants at Glacier National Park, methods for obtaining plants vegetatively were employed. Using heavy-duty leather gloves, cuttings were collected from field plants. Stem tip cuttings taken in early June during bud break but before leaves have expanded were successful. Cuttings were $20 \mathrm{~cm}$ (8 in) in length and $1.5 \mathrm{~cm}(0.6 \mathrm{in})$ in diameter and were recut at the base and treated with 
3000 ppm IBA rooting powder. Cuttings were struck with at least 2 nodes below the surface of rooting medium ( $1: 1 \mathrm{v}: \mathrm{v}$ perlite:sand) in an outdoor mistbed with bottom heat maintained at $22^{\circ} \mathrm{C}\left[72^{\circ} \mathrm{F}\right]$. All cuttings rooted in $8 \mathrm{wk}$ and were potted into 3-1 (1-gal) containers containing the same medium, Osmocote, and Micromax fertilizer described above, but at the rate of $4 \mathrm{~g}(0.14 \mathrm{oz})$ of Osmocote and $2 \mathrm{~g}$ of Micromax per container. Cuttings are grown in the shade house for the remainder of the growing season. Cuttings produce firm root systems in 1 to 1.5 y (Hosokawa and others 2001).

\section{REFERENCES}

Baskin CC, Baskin JM. 1998. Seeds: ecology, biogeography, and evolution of dormancy and germination. San Diego (CA): Academic Press. 666 p.

Hitchcock CL, Cronquist A. 1996. Flora of the Pacific Northwest-an illustrated manual. Seattle (WA): University of Washington Press. 730 p.
Hosokawa J, Wick D, Luna T. 2001. Propagation protocol for vegetative production of container Oplopanax horridus Miq. plants (3 L containers); Glacier National Park, West Glacier, Montana. In: Native Plant Network. URL: http://www.nativeplantnetwork.org (accessed 3 Jan 2001). Moscow (ID): University of Idaho, College of Natural Resources, Forest Research Nursery.

lanson D. 2000. Personal communication. Palmer (AK): Curator, National Arctic Plant Germplasm Unit, Alaska Plant Materials Center.

[ITIS] Integrated Taxonomic Information System. 2000. Biological names. Version 4.0 (on-line database). URL: http://www.itis.usda.gov/plantproj/itis/itis_query.html (accessed 29 Dec 2000).

Kruckeberg A. 1989. Gardening with native plants of the Pacific Northwest. Seattle (WA): University of Washington Press. $252 \mathrm{p}$

Marles R, Clavelle C, Monteleone L, Tays N, Burns D. 1999. Aboriginal plant use in Canada's northwest boreal forest. Vancouver (BC): University of British Columbia Press. 368 p.

Marles R, Farnsworth N. 1995. Antidiabetic plants and their active constituents. Phytomedicine 2:137-189.

Moerman D.1998. Native American ethnobotany. Portland (OR): Timber Press Inc. $927 \mathrm{p}$.

Turner N. 1998. Plant technology of first peoples in British Columbia. Vancouver (BC): University of British Columbia Press. Royal British Columbia Museum Handbook. 256 p.
[USDA] USDA Forest Service, Rocky Mountain Research Station, Fire Sciences Laboratory. 2001. Fire Effects Information System [Online]. URL: http://www.fs.fed.us/database/feis/ plants/shrub/oplhor/ (accessed 3 Jan 2001).

Wick D, Luna T, Evans J, Hosokawa J. 2001. Propagation protocol for production of container Oplopanax horridus Miq. plants $(490 \mathrm{ml}$ containers); Glacier National Park, West Glacier, Montana. In: Native Plant Network. URL: http://www.nativeplantnetwork.org (accessed 3 Jan 2001). Moscow (ID): University of Idaho, College of Natural Resources, Forest Research Nursery.

\section{AUTHOR INFORMATION}

Tara Luna

PO Box 447

East Glacier, MT 59434

tluna@3rivers.net

\section{Propagation Protocol for Poison Oak (Toxicodendron diversilobum)}

KEY WORDS: Anacardiaceae, seed germination, vegetative propagation, revegetation

\section{NOMENCLATURE: USDA NRCS} (1999)

"Why in the world would anyone grow THAT?" is the most common question we hear when someone walks by a healthy crop of poison oak (Toxicodendron diversilobum (Torr. \& Gray) Greene [Anacardiaceae]) in containers at our nursery. Hopefully, they didn't step too close as to have brushed against the plants. If they were wearing shorts on a summer day, they might leave Tree of Life Nursery in good shape, but in a couple days they would remember us with an irritating rash on their legs, and their itch might last more than a week.

Poison oak is an important member of many plant communities in the west from Baja California to British Colum-

\section{MiKe EVANS}

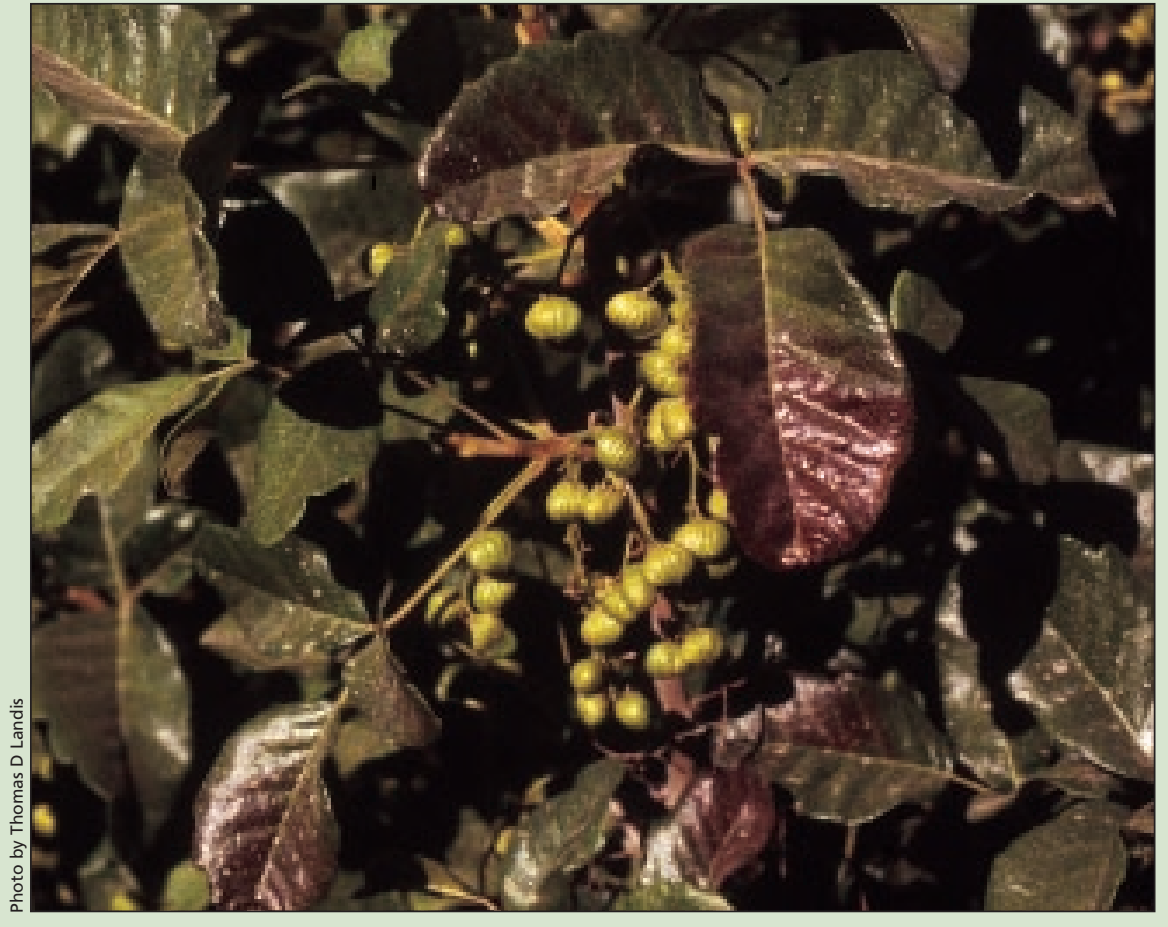

Poison oak (Toxicodendron diversilobum) 
bia. Tree of Life Nursery is a wholesale grower of California native plants for use in ecological restoration and authentic landscapes. So that explains what it is and why we grow it. Poison oak provides valuable habitat for wildlife; cover, nesting materials, and edible berries for the birds. It is an significant component of coastal sage scrub, chaparral, oak woodland, and mixed evergreen forest, usually growing near water or in moist canyon bottoms. Its wide range makes it a well known plant in California-notorious with campers and hikers who try to avoid brushing up against it.

To avoid skin contact, we wear special protective gear when we handle this species in propagation. Seeds can be collected in late summer (the worst time to be near the plant - the leaves are blistering with toxic oils) and the fresh fruit can be stored and handled as dried berries in the fall. Even seeds and berries must be handled with caution because all parts of the plant can cause skin irritation. To simulate digestion by bird species, we scarify seeds by soaking the dried berries in sulphuric acid for $3.5 \mathrm{~h}$. The fruit will disintegrate and the seed coat will be affected to allow more rapid, even germination. After the acid soak, we thoroughly rinse the seed until no trace of acid remains by slowly running fresh water through the seeds all night. Seeds are ready for sowing the next day. We generally like to sow seeds immediately after collection into nursery flats containing a coarse seed germination mix $(1: 1: 1: 1$ [volume basis] perlite, vermiculite, coarse sand, and sphagnum peat moss). Sown flats are placed into a shadehouse and seeds are allowed to germinate during fall, winter, and spring. Winter temperatures at our nursery range from 0 to $13{ }^{\circ} \mathrm{C}(32$ to $55^{\circ} \mathrm{F}$ ). Most germination occurs during fall and spring when soils are warmer. We keep the flats moist during the germination period. Germination can occur in about 3 wk. Seedlings are ready for transplanting into small containers about 2 mo later (see below).

Poison oak is easy to grow from cuttings but we take extreme precautions (Figure 1). By cutting into the stem and exposing the sap, there is a high probability the propagator will get a case of "poison oak" unless they wear protective gear, including a respirator on hot days. If inhaled for a prolonged period, the volatile oils can affect the sensitive areas of the mouth, throat, and lungs. Most firefighters in the west are familiar with the dangers in breathing the smoke of burning poison oak.

With extreme care, we take softwood or semi-hardwood cuttings throughout the year. Of course, the most "convenient" time to do this would be the dormant winter season when the plants are leafless, but handling the stems can still result in skin irritation. The most successful stem cuttings are about $5 \mathrm{~cm}$ (2 in) long and 3 to $9 \mathrm{~mm}$ ( 0.125 to 0.375 in) in caliper. If cuttings are taken during the active growing season, we remove or trim leaves to reduce transpiration during the rooting period. We stick the cuttings with 1 or 2 nodes in the coarse rooting medium (3:3:3:1 [volume basis] course sand, perlite, vermiculite, and sphagnum peat moss). Cutting flats are placed in a humid, cool, greenhouse environment. We experience relatively high humidity levels being only $16 \mathrm{~km}$ (10 miles) from the Pacific Ocean so periodic sprinkling (a few times each day depending on weather) of the cuttings is sufficient. Too much misting results in stem rot. Roots form in 4 to $6 \mathrm{wk}$ and the rooted cuttings can be transplanted into small pots.

Both our 2-mo-old seedlings and 4to 6-wk-old rooted cuttings are transplanted into small containers. We use either $250 \mathrm{ml}$ (2.25 in wide X 3 in deep) or $1050 \mathrm{ml}$ (4 in) containers filled with a 4:1 organic:inorganic (v:v) medium. The organic component is a $1: 2(\mathrm{v}: \mathrm{v})$ mixture of bark:wood shavings and sawdust. The wood components include redwood (Sequoia sempervirens (Lamb. ex D. Don) Endl. [Taxodiaceae]), ponderosa pine (Pinus ponderosa P. \& C. Lawson var. ponderosa [Pinaceae]), and white fir (Abies concolor (Gord. \& Glend.) Lindl. ex. Hildebr. [Pinaceae]). The inorganic component is coarse sand. We also add Osmocote $18 \mathrm{~N}: 6 \mathrm{P}_{2} \mathrm{O}_{5}: 12 \mathrm{~K}_{2} \mathrm{O}(9$ mo release rate at $21{ }^{\circ} \mathrm{C}\left(70{ }^{\circ} \mathrm{F}\right)$ at a rate of about $2.7 \mathrm{~kg} / \mathrm{m}^{3}\left(4.5 \mathrm{lb} / \mathrm{yd}^{3}\right)$ and inoculum of the vesicular arbuscular mycorrhiza Glomus intraradices via Grolife (Gro-Power, Chino, California) at a rate of $6 \mathrm{~kg} / \mathrm{m}^{3}\left(10 \mathrm{lb} / \mathrm{yd}^{3}\right)$. Plants generally stay in these containers a couple of

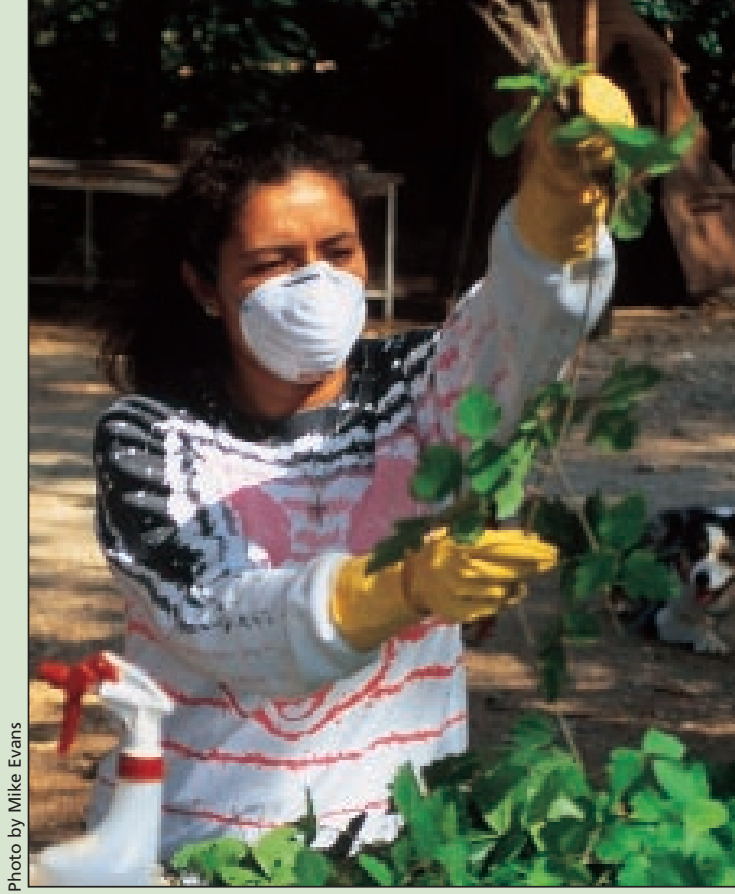

Figure 1 Protective gear must be worn when taking poison oak cuttings.

months before being transplanted up to 3-1 (1-gal) containers that are filled with the same medium and fertilizer. Poison oak in nursery containers prefers light shade and plenty of water. It is a rapid grower and we have saleable plants in 6 to 9 mo.

Certainly poison oak is not an appropriate choice for any use other than wildlife habitat in ecological restoration projects. However, if it is omitted at a revegetation jobsite within its native range, an essential component of the plant community will be missing. Native plant nurseries can play an important role by producing all the key plant species needed for habitat restoration. . . even those we consider "less desirable" from our human perspective.

\section{REFERENCE}

USDA NRCS. 1999. The PLANTS database, Version 3.0. URL: http://plants.usda.gov/plants (accessed 7 May 2001). Baton Rouge (LA): National Plant Data Center. 


\section{Propagation Protocol for Stinging Nettle (Urtica dioica)}

KEY WORDS: seed propagation, stem cuttings, divisions

NOMENCLATURE: ITIS (2000)

Stinging nettle (Urtica dioica L. [Urticaceae]) is found throughout temperate regions of the world, commonly growing in rich soils in forest clearings, stream banks, old fields, and waste places. It is a common component of riparian communities. In the eastern and midwestern US, it occurs as far south as Virginia, Missouri, and Kansas. It ranges from Alaska south to central California and through the Rocky Mountains to Mexico.

It is an herbaceous perennial plant with opposite leaves that are sharply toothed and commonly grows to 1 to 3 $\mathrm{m}$ (3 to $9 \mathrm{ft})$ tall. It is strongly rhizomatous and spreads vegetatively once established. Leaves and stems are covered with hollow, fluid-filled hairs that break off when touched, leaving a sharp point like a miniature hypodermic needle that allows the fluids to enter the skin and cause stinging or blistering. The compounds causing the unpleasant effect are reported to be a histamine and acetylcholine (Boufford1997). Inconspicuous flowers are greenish and are borne in drooping clusters at the stem nodes. Flowers are unisexual, staminate, or pistillate or borne in separate inflorescences or sometimes intermixed in the same inflorescence. Plants flower in late spring or early summer and seeds form by late August or early September. The fruit is a tiny hard-coated achene.

Four subspecies are recognized. Urtica dioica ssp. dioica is the most common and is distinct by having pistillate and staminate flowers on separate plants and stinging hairs on both surfaces of the leaf blade. The other 2 subspecies (gracilis and holosericea) have pistillate and staminate flowers on the same plant. Urtica dioica ssp. gracilis has mostly glabrous stems with a few stinging hairs while Urtica dioica ssp.

\section{TARA LUNA}

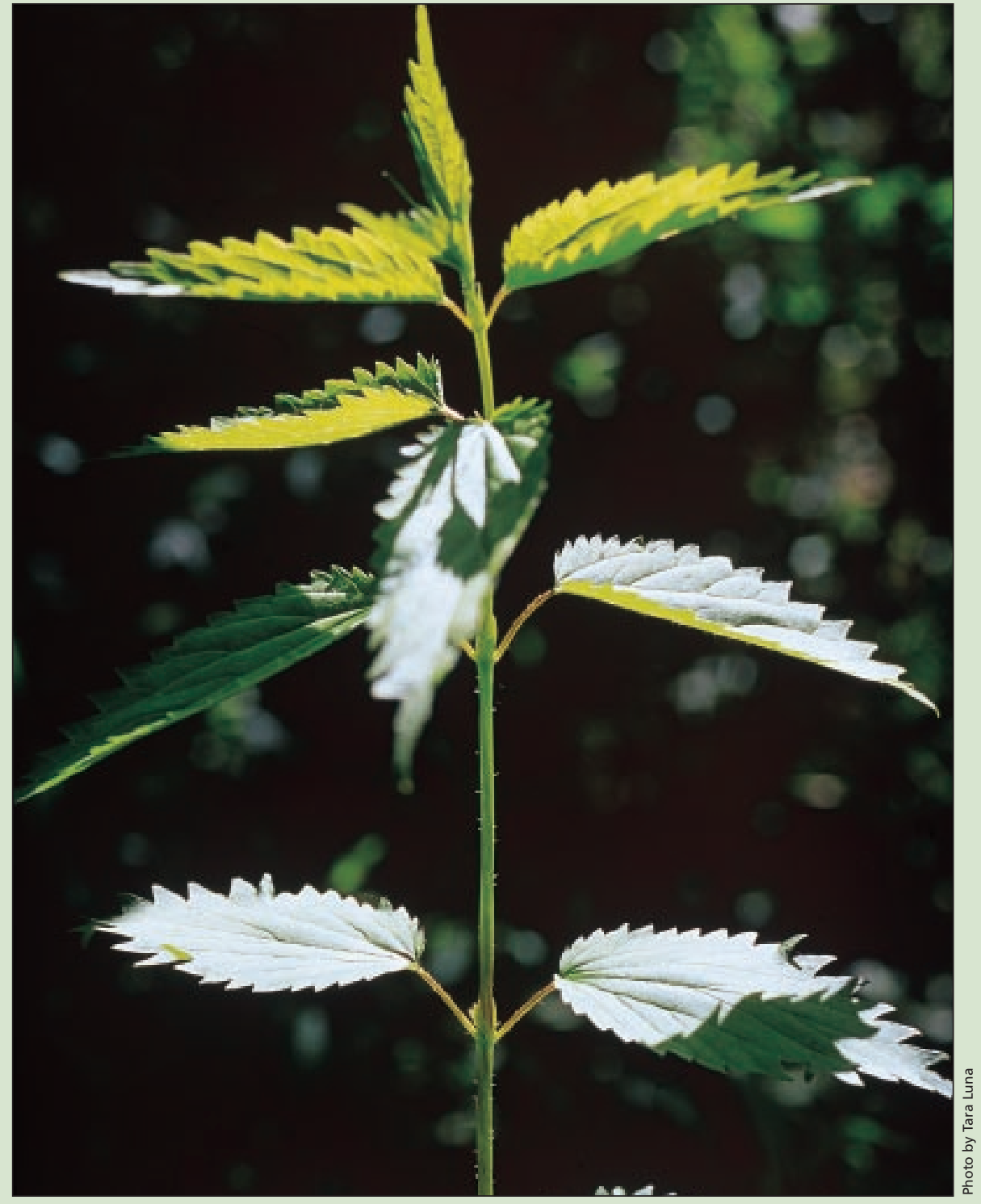

Stinging nettle (Urtica dioica)

holosericea has softly hairy stems with stinging hairs.

Stinging nettle has a long history of use by people throughout the Northern Hemisphere. The common name is thought to be derived from Anglo Saxon "noedl," meaning "a needle," alluding to its sharp sting or use as a thread for sewing before the introduction of flax. Nettle fiber is very similar to hemp or flax and was used for fine textiles, sail cloth, and rope for centuries in Europe. Its use as a fiber disappeared after the introduction of flax, but it was used again for army clothing during flax shortages of World War I. Roots yield a yellow dye and leaves yield a green dye used in Russia for woolens (Philips and Foy 1990).

Nettle fiber was widely used by many groups of American Indians for thousands of years as a source of fiber 
for bowstrings, fishing nets and lines, snares, and cordage. The Dakota, Ponca, and Winnebago tribes wove special ceremonial nettle cloth for bundles (Moerman 1998).

Nutritionally, stinging nettle is high in vitamins $\mathrm{A}, \mathrm{C}, \mathrm{D}$, and minerals iron, manganese, potassium, and calcium. It contains $21 \%$ to $23 \%$ crude protein and $9 \%$ to $21 \%$ crude fiber. Young leaves are collected in early spring and prepared like spinach. Drying or cooking removes the stinging hairs. Nettles were used throughout North America, Europe, and Asia as a culinary plant, in salads and soups or as a cooked vegetable. It is important to remember to use only the young leaves; steam or dry before taking internally as a medicinal or food!

Stinging nettle has several medicinal properties: astringent, tonic, antiasthmatic, and diuretic. In Europe, it was widely used for the treatment of dropsy, gout, rheumatism, and for weight loss. It was also widely used as far back as ancient Greece as an astringent for the removal of kidney stones and as a urinary aid (Gerard 1633). The practice of flogging with nettle (urtification) was used as an anti-rheumatic treatment since ancient Greece and Rome. Romans introduced the southern species, $U$. pilofera, to the British islands, as they believed flogging with the plant would be necessary to stay warm!

Many American Indian tribes also used nettle medicinally as an anti-rheumatic (they also practice urtification), for urinary disorders, as an orthopedic aid and as a hemostat for bloody noses (Marles and others 2000). Nettle roots are used to relieve eczema and dandruff and are reputed to stimulate hair growth. Today, nettle root extract is commonly found as a component of many shampoos and conditioners. Roots are harvested in the fall.

With such a long history of so many uses throughout the world, it is hard to be too upset with the plant for long. Usually the itching or burning sensation subsides in 7 to $10 \mathrm{~min}$ and is known by many outdoor enthusiasts as the 7 min itch!

\section{PROPAGATION}

Stinging nettle can be propagated by seeds or vegetatively by divisions.

Propagation of the plant for home use or by commercial herb farms is desired. Nettle may also have potential for restoration in suitable habitats as it readily establishes in disturbed moist ground. Seeds can be collected using gloves by hand stripping the female inflorescences or cutting the tops. Seeds exhibit physiological dormancy and most likely require a prolonged stratification period to soften the hard seed coats and break the physiological dormancy (Baskin and Baskin 1998). Germination is reported at alternating temperatures of 25 and $15^{\circ} \mathrm{C}$ following a warm stratification and in the presence of light on seeds that were dry stored for 3 mo (Grime and others 1981). Seeds can be sown in late fall with germination occurring the following spring or summer.

Divisions of established plants are another propagation method since this species spreads vigorously by rhizomes. Nettles prefer nitrogen rich soils in the wild so using a rich potting medium and regular fertilization will result in healthy nursery stock.

\section{REFERENCES}

Baskin CC, Baskin JM. 1998. Seeds: Ecology, biogeography, and evolution of dormancy and germination. San Diego (CA): Academic Press. $666 \mathrm{p}$.

Boufford D. 1997. Urticaceae-nettle family. In: Flora of North America editorial committee (editors). Flora of North America. Volume 3, Magnoliophyta: Magnoliidae and

Hamamelidae. New York (NY): Oxford University Press. p 400-403.

Gerard J. 1633 (reprinted 1975). The herbal or general history of plants. New York (NY): Dover Publications. $1631 \mathrm{p}$.

Grime JP, Mason G, Curtis A., Rodman J, Band S, Mowforth M, Neal A, Shaw S. 1981. A comparative study of germination characteristics in a local flora. Journal of Ecology 69:1017-1059.

[ITIS] Integrated Taxonomic Information System. 2000. Biological names. Version 4.0 (on-line database). URL: http://www.itis.usda.gov/plantproj/itis/itis_query.html (accessed 29 Dec 2000).

Marles R, Clavelle C, Monteleone L, Tays N, Burns D. 1999. Aboriginal plant use in Canada's northwest boreal forest. Vancouver (BC): University of British Columbia Press. $368 \mathrm{p}$.

Moerman D.1998. Native American ethnobotany. Portland (OR): Timber Press Inc. 927 p.

Philips R, Foy N. 1990. Herbs. New York (NY): Random House Publishing Inc. 192 p.

Universityofldaho

\section{College of Natural Resources}

\section{An integrated approach to understanding the ecology and management of ecosystems.}

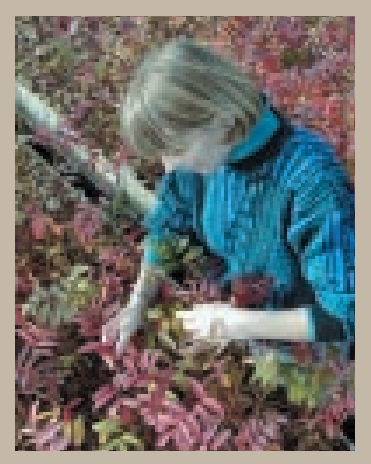

Undergraduate (BSc) and graduate (MSc and $\mathrm{PhD}$ ) degrees in:

- Ecology and Conservation Biology

- Fish and Wildlife Resources

- Forest Products

- Forest Resources

- Rangeland Ecology and Management

- Resource Recreation and Tourism

- Interdisciplinary Master of Natural Resources

Native plant research and production at the Forest Research Nursery

Web site: www.uidaho.edu/cnr E-mail: cnr@uidaho.edu

College of Natural Resources, University of Idaho,

Moscow, Idaho 83844-I I 30 208-885-7302

An AA/EO employer and educational institution

AUTHOR INFORMATION

Tara Luna

PO Box 447

East Glacier, MT 59434 tluna@3rivers.net 


\section{Propagation Protocol for Poison Sumac (Toxicodendron vernix)}

JENNIFER KUJAWSKI

KEY WORDS: native wetland shrub, Anacardiaceae, revegetation, seed germination

NOMENCLATURE: USDA NRCS (1999)

Deep in the heart of southeastern Washington, DC, lives a very nasty plant. Hidden among enticing highbush blueberries (Vaccinium corymbosum $\mathrm{L}$. [Ericaceae]) and sweetbay magnolias (Magnolia virginiana L. [Magnoliaceae]) is poison sumac (Toxicodendron vernix (L.) Kuntze [Anacardiaceae]), waiting to brush the unwary visitor with a dose of its itching oil. Poison sumac is closely related to other such nasties as poison ivy (Toxicodendron radicans (L.) Kuntze), the poison oaks (Toxicodendron pubescens $\mathrm{P}$. Mill. and Toxicodendron diversilobum (Torr. \& Gray) Greene), and the benign, nonpoisonous sumacs (Rhus spp. L.), all members of the cashew family

(Anacardiaceae).

Poison sumac is a multi-stemmed, deciduous shrub that grows to $5 \mathrm{~m}$ (16 $\mathrm{ft}$ ) tall. Its stems, when broken, exude a milky sap. It has compound leaves composed of 7 to 13 oblong leaflets that have entire margins (unlike Rhus spp. that have serrated leaf edges). The leaves are hairless and smooth, with petioles that are reddish or maroon. The leaves turn yellow or red in fall, a characteristic common to most sumacs. Plants in the vegetative stage may be confused with young ash (Fraxinus L. [Oleaceae]) saplings (Magee 1981).

The flowers of poison sumac are not particularly noticeable; they are tiny, green, and form drooping clusters (up to $20 \mathrm{~cm}$ [8 in] long) from leaf axils in May and June. In contrast, poison sumac fruit is distinctive and a key feature of the species. Each fruit is a creamy white drupe about 4 to $5 \mathrm{~mm}$ ( $0.18 \mathrm{in})$ in size and makes up part of a dangling cluster. Fruit, leaves, and other juicy parts of poison sumac contain an oil called urushiol that causes an allergic rash at any time of the year when susceptible individuals touch the plant (AAD 1999).

Poison sumac grows in swamps, wet woodlands, and shrub-tree bogs, usually in the shade. It is a species found in threatened mid-Atlantic coastal plain "magnolia bogs" as described by McAtee (1918) in the early part of the 20th century. Its range is from southern Maine and southwestern Nova Scotia to Minnesota and southwestern Ontario, south to

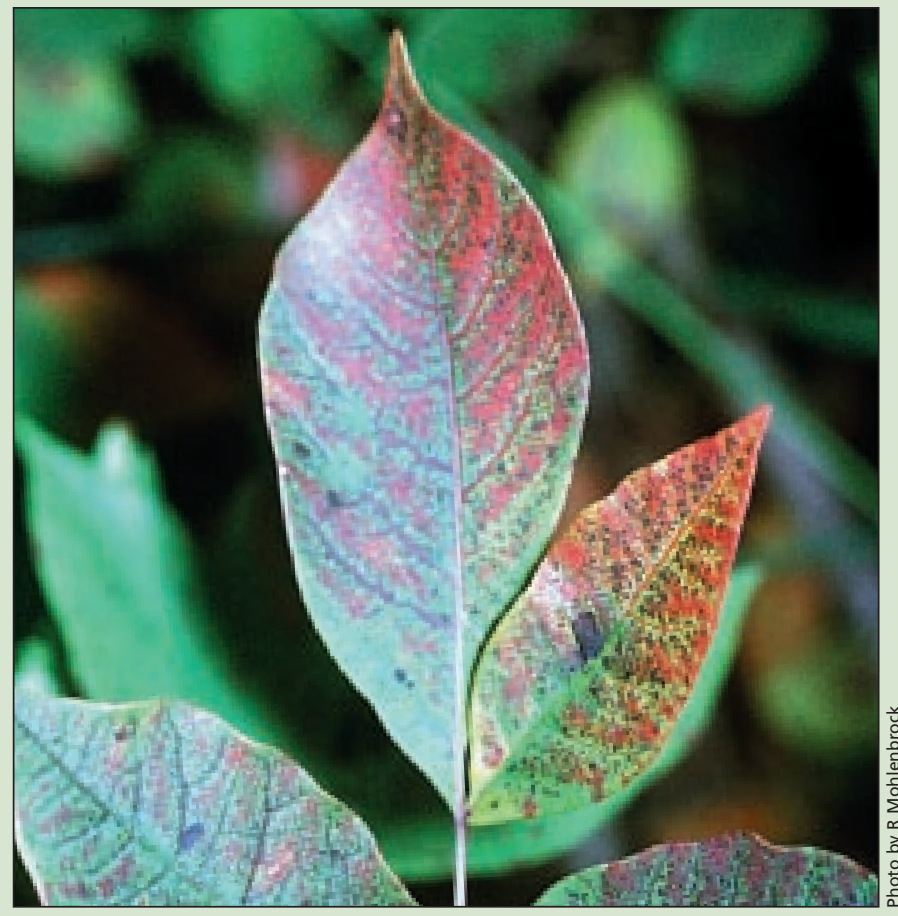
Poison sumac Maryland, Ohio, and Indiana, and along the coast from Delaware to Florida and Texas (Gleason and Cronquist 1991).

\section{RATIONALE FOR PROPAGATION}

Posion sumac was propagated for a revegetation project at Oxon Run Parkway in southeastern Washington, DC. Oxon Run is a "stream corridor park that contains several northern magnolia bogs and a rare wetland complex, the only such example in the national park system" (Rudy 2000) and has been impacted over the years by US Army ordnance testing during World War I, subway tunnel construction beneath the bog, runoff from an adjacent hospital parking lot, and urban pollution.

To mitigate the effects of unexploded ordnance removal and other recent activities at Oxon Run, the National Park Service asked the National Plant Materials Center (NPMC) to propagate and transplant a number of representative magnolia bog species, including poison sumac. All propagules were collected on site.

\section{PROPAGATION}

We propagated poison sumac from seeds. Ripe seeds were collected in late summer (end of August at Oxon Run Parkway); collectors wore long sleeves and latex gloves. After seeds were brought back to the NPMC, processing procedures similar to those for Rhus species (Brinkman 1974) were used. Seeds were allowed to dry for several weeks, after which they were rubbed over a wire screen or wire kitchen strainer to remove the outer white seedcoat and any remaining pulp. Cleaned seeds were stored dry in paper envelopes at $4{ }^{\circ} \mathrm{C}\left(40{ }^{\circ} \mathrm{F}\right)$ and $35 \%$ relative humidity. Because we collected so few seeds, we did not experiment with pre-germination treatments, but seeds may benefit from a scarification treatment, as is the case with poison oak (Evans 2001) and related Rhus spp. 
(Brinkman 1974). Our nonscarified poison sumac seeds had only 3\% germination.

Seeds were sown in late winter on Sunshine Mix \#1 (containing sphagnum peat moss, perlite, major and minor nutrients, gypsum, dolomitic lime, and a wetting agent; Sun Gro Horticulture Inc, Bellevue, Washington). Seed flats were set on a bench in the greenhouse under natural light and were hand watered as needed. Greenhouse temperatures ranged from 26 to $29^{\circ} \mathrm{C}$ ( 80 to $85^{\circ} \mathrm{F}$ ) during the day, while night temperatures were maintained at 18 to $20{ }^{\circ} \mathrm{C}\left(65\right.$ to $\left.68{ }^{\circ} \mathrm{F}\right)$. By late spring, seeds had germinated. Seedlings were transplanted into 1-1 (quart) containers using a woody plant potting mix composed of $2011\left(7.1 \mathrm{ft}^{3}\right)$ Sunshine Mix \#1, 1131 ( $\left.4 \mathrm{ft}^{3}\right)$ of shredded pine bark mulch, and $565 \mathrm{~g}(20 \mathrm{oz})$ Nutricote Total $18 \mathrm{~N}: 8 \mathrm{P}_{2} \mathrm{O}_{5}: 6 \mathrm{~K}_{2} \mathrm{O}(270 \mathrm{~d}$ release rate at $\left.25^{\circ} \mathrm{C}\left[77^{\circ} \mathrm{F}\right]\right)$. Staff wore latex gloves at all times when handling seeds, as well as long sleeves when working with container plants. Seedlings were moved outside to a shade house during the first season; quart pots were overwintered in a cold storage room at $4{ }^{\circ} \mathrm{C}(40$ ${ }^{\circ} \mathrm{F}$ ) and $60 \%$ relative humidity. During the second growing season, seedlings were transplanted into 3-1 (1-gal) containers using the same woody plant mix that was used for quarts. These larger plants were overwintered outside under a 6-mm-thick (0.25-in) microfoam insulating blanket and were ready for outplanting in spring of the third growing season.

\section{AUTHOR INFORMATION}

Jennifer Kujawski

Resource Conservationist

USDA Natural Resource

Conservation Service

National Plant Materials Center

BARC-East, Building 509

Beltsville, MD 20705

jennifer.kujawski@md.usda.gov

\section{REFERENCES}

[AAD] American association of dermatology. 1999. Poison plants: ivy, sumac, oak. URL: http://www.aad.org/pamphlets/Poisonlvy.html (accessed 7 Jan 2001).

Evans M. 2001. Propagation protocol for poison oak (Toxicodendron diversilobum). Native Plants Journal 2:108-109.

Gleason HA, Cronquist A. 1991. Manual of vascu lar plants of the northeastern United States and adjacent Canada. 2nd ed. Bronx (NY): The New York Botanical Garden. 910 p.

Brinkman K A. 1974. Rhus L. Sumac. In: Schopmeyer CS, technical coordinator. Seeds of woody plants in the United States. Washington (DC): USDA Forest Service. Agriculture Handbook 450. p 715-719.

Magee DW. 1981. Freshwater wetlands: a guide to common indicator plants of the Northeast. Amherst (MA): University of Massachusetts Press. 245 p.

McAtee WL. 1918. Magnolia bogs near Washington, D.C., and their relation to the pine barrens. Bulletin of the Biological Society of Washington 1:74-90.

Rudy S. 2000. Interagency cleanup of a former Army camp at Oxon Run. Park Science 20(1):5-6.

USDA NRCS. 1999. The PLANTS database, Version 3.0. URL: http://plants.usda.gov/plants (accessed 7 Jan 2001). Baton Rouge (LA): National Plant Data Center.

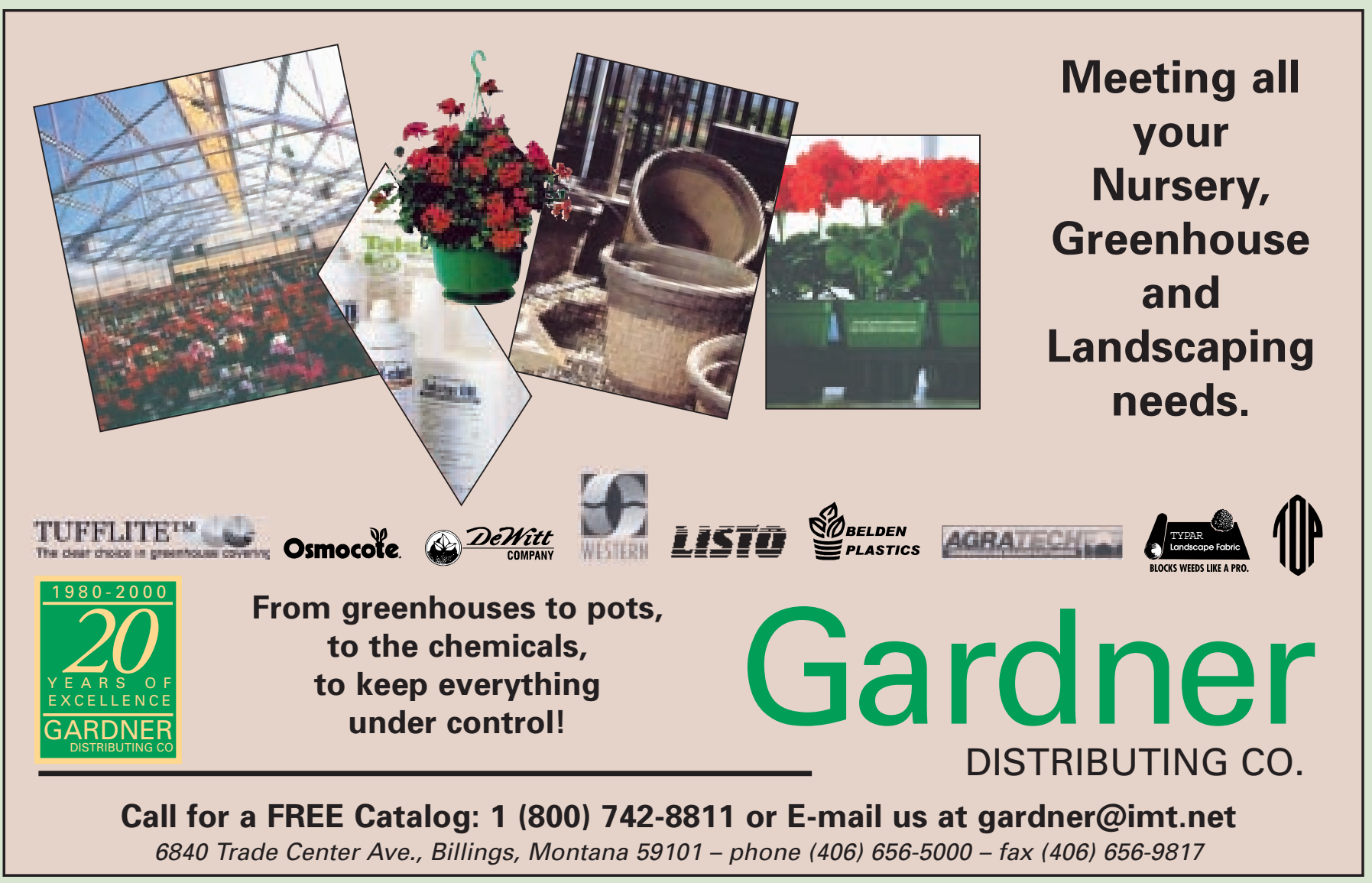

